\title{
Misinterpretations of the HACCP MS 1480: 2007 towards Food Safety System Certification
}

\author{
Mohd Bakri Jali 1,2*, Maaruf Abdul Ghani ${ }^{1}$, Norazmir Md Nor ${ }^{3}$ \\ ${ }^{1}$ Faculty of Science \& Technology, Universiti Kebangsaan Malaysia, 43600 Bangi, Selangor, Malaysia \\ 2 SIRIM Training Services Sdn Bhd, Persiaran Dato' Menteri, 40700 Shah Alam, Selangor, Malaysia \\ ${ }^{3}$ Faculty of Health Sciences, Universiti Teknologi MARA, 42300 Puncak Alam, Selangor, Malaysia
}

\begin{abstract}
Hazard Analysis Critical Control Point (HACCP) is a food safety system through seven principles to control a biological, chemical and physical hazard. Principles 1 and 2 are the backbones of the HACCP system. However, there are some misinterpretations in practice HACCP Principles 1 and 2 of the identification stage, analysis of hazards, control measures and CCP determination. The usage of a multi-hazard analysis form without a standard format has led to inconsistencies in the analysis of hazard analysis; determination of controls and subsequent determination of CCP affect the implementation of HACCP document and product safety to the consumers.
\end{abstract}

(C) 2016. The Authors. Published for AMER ABRA by e-International Publishing House, Ltd., UK. Peer-review under responsibility of AMER (Association of Malaysian Environment-Behaviour Researchers), ABRA (Association of Behavioural Researchers on Asians) and cE-Bs (Centre for Environment-Behaviour Studies), Faculty of Architecture, Planning \& Surveying, Universiti Teknologi MARA, Malaysia.

Keywords: Food safety; food hygiene; GMP; HACCP

\section{Introduction}

Hazard Analysis and Critical Control Point (HACCP) is not just an international standard, but all food industries internationally and domestically need to make this system as a daily practice. The Malaysian Government through the Ministry of Health (MOH) has developed the HACCP Certification Scheme for companies that have met the criteria of the HACCP as per guideline (Merican, 2000).

HACCP system is not a system that stands by its own. HACCP requires a component of another system known as prerequisites programs (PRP). PRP practiced in the food safety management system is based on the requirements of the Good

${ }^{*}$ Corresponding author. Tel.: +6-019-389-2321; fax: +6-03-3258-4599.

E-mail address: mbakri@sirim.my

(C) 2016. The Authors. Published for AMER ABRA by e-International Publishing House, Ltd., UK. Peer-review under responsibility of AMER (Association of Malaysian Environment-Behaviour Researchers), ABRA (Association of Behavioural Researchers on Asians) and cE-Bs (Centre for EnvironmentBehaviour Studies), Faculty of Architecture, Planning \& Surveying, Universiti Teknologi MARA, Malaysia.

DOI: https://doi.org/10.21834/e-bpj.v1i2.251 
Manufacturing Practice (GMP). In Malaysia, the GMP and HACCP requirements respectively refer to Standard MS 1514: 2009 Good Manufacturing Practice for Food and MS 1480: 2007-Food Safety according To Hazard Analysis Critical Control Point.

HACCP is a safety and quality management tools developed by Pillsbury Corporation in the 1960s (Bennet \& Steed, 1999). HACCP system development is intended to reduce the dependence on testing of the end product (Soon et al., 2011). Application of the HACCP system has been received well in developed countries as well as developing countries like Malaysia. Obstacles and problems that occur in developing countries now is similar to what has been identified to happen to small and medium enterprises in developed countries (Karl \& Angus, 2000).

Despite, the improvements in the implementation of HACCP at the international level and the rest of the world, but there is still misconception and confusion about it. If the error of this concept continues, then it will affect the image of HACCP and its benefits to the public. Motarjemi and Kaferstein (1999) have been underlining some misconceptions of HACCP as follows:

- HACCP is a new methodology that replaced food safety assurance that previously based on the application of good hygiene practice

- HACCP is a burden in addition to legislation

- HACCP system involves some documentation and extensive records

- HACCP system requires a lot of resources

- HACCP is not effective because it could not ensure the safety of agricultural products and raw materials.

- The approach of authorities to implement HACCP system to prevent foodborne.

- Application system of HACCP in small and medium enterprises is impossible.

Certainly, HACCP is not a cure medicine to all the problems arising about food safety. HACCP is a tool to guide the employee in ensuring food safety by considering all aspects of security and ensure that the thing to do is made. HACCP implementation requires an understanding of its principles and commitment to implement them. HACCP system itself does not make food produced safe, but the correct implementation does (Motarjemi \& Kaferstein, 1999). Although HACCP system has nearly 55 years executed, still there is a problem in the confusion to implement HACCP Principle 1 (conduct a hazard analysis) and Principle 2 (identify critical control points) out of 7 HACCP Principles (Wallace et al. 2014).

These review paper aims to determine the major challenges faced by SMEs in implement HACCP especially the first two principles; and how these challenges influence the capability of SMEs towards food safety scheme certification.

\section{Methodology}

Based on review of 20 journal articles as well as reports from Malaysian Investment Development Authority (MIDA), Performance Management and Delivery Unit (PEMANDU), Food Safety and Quality Division (Ministry of Health) and Standards and Industrial Research Institute of Malaysia (SIRIM); the major challenges faced by SMEs in implement HACCP were determined. It is also investigated on how these challenges influence the capability of SMEs towards food safety scheme certification. Major issues such as SMEs capabilities to fulfill minimum standard requirements and sustainability HACCP practice are identified to be problems that could arise. These issues were analysed in connection with SME's difficulties to design a hygienic, efficient and sustainable premises. The analysis was based on a comprehensive review of Malaysian authoritative reports, standard requirements and data of journal articles, scholarly books, and magazines, newspapers as well as information obtained.

\section{Results and Discussion}

\subsection{Format of hazard analysis}

Several formats can be used to perform a hazard analysis. The format used can be ranged from a simple format to a complex one. The variety of hazard analysis formats from various sources of reference materials either in the country or the international level sometimes confusing industry and consultants. The use of those formats does not provide a significant effect on the hazard analysis, but, what is more, important is the content the information in it is a priority. However, this confusion will result in nonconformity during the audit activities of the third party or internal verification. 
According to Schmidt and Newslow (2013), if the industry operates under certain HACCP regulations, they are encouraged to use the format of the hazard analysis according to what was proposed by the authorities. This statement is a reminder for compliance with the requirements prescribed to avoid hazard analysis rejected by the authority. The following is an example of the format of the analysis used for hazard analysis such as Table 1 - Table 4.

Table 1. Format of hazard analysis format (FDA HACCP, 2001)

\begin{tabular}{|l|l|l|l|l|l|}
\hline$(1)$ & $(2)$ & $(3)$ & $(4)$ & $(5)$ & $(6)$ \\
\hline $\begin{array}{l}\text { Raw materials } \\
\text { And process } \\
\text { steps }\end{array}$ & $\begin{array}{l}\text { Identify potential } \\
\text { hazards introduced, } \\
\text { controlled, or } \\
\text { enhanced at this } \\
\text { step. }\end{array}$ & $\begin{array}{l}\text { Assess the severity } \\
\text { or significance of } \\
\text { each hazard }\end{array}$ & $\begin{array}{l}\text { Justify your } \\
\text { decision for } \\
\text { assessment in } \\
\text { column 3 }\end{array}$ & $\begin{array}{l}\text { What control measure } \\
\text { can be applied to } \\
\text { prevent, eliminate or } \\
\text { reduce the hazard to } \\
\text { an acceptable level? }\end{array}$ & $\begin{array}{l}\text { Is this step a } \\
\text { Critical } \\
\text { Control Point } \\
\text { (CCP)? }\end{array}$ \\
\hline & & & & & \\
\hline
\end{tabular}

Table 2. Format of hazard analysis (USDA/ FSIS HACCP, 2005)

\begin{tabular}{|l|l|l|l|l|l|}
\hline$(1)$ & $(2)$ & $(3)$ & $(4)$ & $(5)$ & $(6)$ \\
\hline $\begin{array}{l}\text { Raw materials } \\
\text { and process } \\
\text { steps }\end{array}$ & $\begin{array}{l}\text { Potential hazards } \\
\text { introduced, } \\
\text { controlled, or } \\
\text { enhanced at this } \\
\text { step. }\end{array}$ & $\begin{array}{l}\text { Does this potential } \\
\text { hazard need to be } \\
\text { addressed in the } \\
\text { HACCP Plan? } \\
\text { (Yes/No) }\end{array}$ & $\begin{array}{l}\text { (Why?) } \\
\text { (Justification for } \\
\text { decision made } \\
\text { in the previous } \\
\text { column) }\end{array}$ & $\begin{array}{l}\text { What measures can be } \\
\text { applied to prevent, } \\
\text { eliminate, or reduce the } \\
\text { hazard being addressed } \\
\text { in your HACCP Plan? }\end{array}$ & $\begin{array}{l}\text { Is this step a } \\
\text { Critical } \\
\text { Control point } \\
\text { (CCP)? }\end{array}$ \\
\hline & & & & & \\
\hline
\end{tabular}

Table 3. Format of hazard analysis (Wallace et al., 2011)

\begin{tabular}{|l|l|l|l|l|l|l|l|}
\hline$(1)$ & $(2)$ & $(3)$ & $(4)$ & $(5)$ & $(6)$ & $(7)$ & $(8)$ \\
\hline $\begin{array}{l}\text { Raw } \\
\text { materials and } \\
\text { process steps }\end{array}$ & $\begin{array}{l}\text { Hazard: source, } \\
\text { cause and } \\
\text { manifestation }\end{array}$ & $\begin{array}{l}\text { Likelihood of } \\
\text { occurrence } \\
\text { (high/low) }\end{array}$ & $\begin{array}{l}\text { Severity } \\
\text { (high/low) }\end{array}$ & $\begin{array}{l}\text { Significant? } \\
\text { (Yes/No) }\end{array}$ & $\begin{array}{l}\text { Justification of } \\
\text { significance } \\
\text { decision }\end{array}$ & $\begin{array}{l}\text { Control } \\
\text { Measure }\end{array}$ & $\begin{array}{l}\text { Justification } \\
\text { of control } \\
\text { measure }\end{array}$ \\
\hline & & & & & & & \\
\hline
\end{tabular}

Table 4. Format of hazard analysis (MS 1480: 2007)

\begin{tabular}{|l|l|l|l|l|l|}
\hline$(1)$ & $(2)$ & $(3)$ & $(4)$ & $(5)$ & $(6)$ \\
\hline $\begin{array}{l}\text { Raw } \\
\text { materials and } \\
\text { process steps }\end{array}$ & $\begin{array}{l}\text { Potential hazard } \\
\text { state whether } \\
\text { biological, chemical } \\
\text { or physical }\end{array}$ & $\begin{array}{l}\text { Rational for } \\
\text { inclusion or } \\
\text { exclusion as a } \\
\text { hazard }\end{array}$ & $\begin{array}{l}\text { Is this a } \\
\text { significant } \\
\text { hazard? } \\
\text { (Yes/No) }\end{array}$ & $\begin{array}{l}\text { What measures can } \\
\text { be applied to control } \\
\text { this significant hazard? }\end{array}$ & $\begin{array}{l}\text { Is this process } \\
\text { steps a CCP? } \\
\text { (Yes/No) }\end{array}$ \\
\hline & & & & & \\
\hline
\end{tabular}

Most of the format of the hazard analysis established, the first thing that needs to be completed for the hazard analysis is a list of food hazard in the raw materials or process steps. The industry is encouraged to use a different format for the hazard analysis of raw materials and the process steps in order gain more focus. All the hazards of biological, chemical and physical listed during the identification must be specific rather than simply using common terminology such as 'dangers pathogen' and 'chemical hazards should be avoided' (Schmidt \& Newslow 2013; Wallace et al. 2011). Schmidt and Newslow (2013) have 
proposed at the time of hazard analysis; it is important to be more specific and more detailed information. If there are several potential hazards similar to their features, they can be classified in the same group. For example, 'vegetative pathogens', 'pathogen forming spores', pathogens cause infection' or 'pathogens produce toxins' might be able to use the note reference to determine the specific pathogens.

There is a difference the next steps in a format used for hazard analysis compared to hazard analysis in MS 1480: 2007. In MS 1480: 2007, a next step after the identification of potential hazards is rational for inclusion and exclusion as a hazard. While in other formats next step is the assessment of the hazard and followed by the justification of assessments made. On the other hand, the hazard assessment in MS 1480: 2007 is done after the justification given. This situation rises too much confusion because of the HACCP team had to make justification against inclusion or exclusion hazard without strong fundamentals, in particular to the HACCP team newly formed. This situation allows the HACCP team with an arbitrary decision to provide justification for the exception of the hazards because the next steps of the hazard assessment can be made of inclusion hazard only. The situation is illustrated in Table 5 - Table 8 below.

Table 5. Example of exclusion with hazard analysis without control measure

\begin{tabular}{|c|c|c|c|c|c|c|c|c|}
\hline (1) & (2) & (3) & (4) & & & & (5) & (6) \\
\hline \multirow{2}{*}{$\begin{array}{l}\text { Raw materials } \\
\text { and process } \\
\text { steps }\end{array}$} & \multirow{2}{*}{$\begin{array}{l}\text { Potential hazard state } \\
\text { whether biological, } \\
\text { chemical or physical }\end{array}$} & \multirow{2}{*}{$\begin{array}{l}\text { Rational for inclusion } \\
\text { or exclusion as a } \\
\text { hazard }\end{array}$} & \multicolumn{4}{|c|}{$\begin{array}{l}\text { Is this a significant } \\
\text { hazard? } \\
\text { (Yes/No) }\end{array}$} & \multirow{2}{*}{$\begin{array}{l}\text { What measures } \\
\text { can be applied to } \\
\text { control this } \\
\text { significant } \\
\text { hazard? }\end{array}$} & \multirow{2}{*}{$\begin{array}{l}\text { Is this process } \\
\text { steps a CCP? } \\
\text { (Yes/No) }\end{array}$} \\
\hline & & & sev & lik & sig & $\mathrm{Y} / \mathrm{N}$ & & \\
\hline $\begin{array}{l}\text { Transferring } \\
\text { cooked } \\
\text { product to } \\
\text { container }\end{array}$ & $\begin{array}{l}\text { Biology: } \\
\text { Contamination of } \\
\text { pathogenic microbe } \\
\text { such as coliforms, } \\
\text { B.cereus, E.coli, } \\
\text { Salmonella. }\end{array}$ & $\begin{array}{l}\text { Exclusion: } \\
\text { Likely to occur due to } \\
\text { cross contamination. } \\
\text { Could be eliminated } \\
\text { through proper } \\
\text { personnel hygiene. }\end{array}$ & 3 & 2 & 6 & $\mathrm{~N}$ & $\begin{array}{l}\text { No control } \\
\text { measure required }\end{array}$ & No \\
\hline
\end{tabular}

Table 6. Example of exclusion without hazard analysis but control measure is established

\begin{tabular}{|c|c|c|c|c|c|c|c|c|}
\hline (1) & (2) & (3) & \multicolumn{4}{|l|}{ (4) } & (5) & (6) \\
\hline \multirow{2}{*}{$\begin{array}{l}\text { Raw } \\
\text { materials and } \\
\text { process } \\
\text { steps }\end{array}$} & \multirow{2}{*}{$\begin{array}{l}\text { Potential hazard } \\
\text { state whether } \\
\text { biological, chemical } \\
\text { or physical }\end{array}$} & \multirow{2}{*}{$\begin{array}{l}\text { Rational for } \\
\text { inclusion or } \\
\text { exclusion as a } \\
\text { hazard }\end{array}$} & \multicolumn{4}{|c|}{$\begin{array}{l}\text { Is this a significant } \\
\text { hazard? } \\
\text { (Yes/No) }\end{array}$} & \multirow{2}{*}{$\begin{array}{l}\text { What measures can be } \\
\text { applied to control this } \\
\text { significant hazard? }\end{array}$} & \multirow{2}{*}{$\begin{array}{l}\text { Is this process } \\
\text { steps a CCP? } \\
\text { (Yes/No) }\end{array}$} \\
\hline & & & sev & lik & sig & $\mathrm{Y} / \mathrm{N}$ & & \\
\hline $\begin{array}{l}\text { Transferring } \\
\text { cooked } \\
\text { product to } \\
\text { container }\end{array}$ & $\begin{array}{l}\text { Physical: } \\
\text { External foreign } \\
\text { bodies such as dust } \\
\text { and hair. }\end{array}$ & $\begin{array}{l}\text { Exclusion: } \\
\text { Likely to occur if } \\
\text { product } \\
\text { exposed. }\end{array}$ & - & - & - & - & $\begin{array}{l}\text { Could be eliminated by } \\
\text { covering cooked food } \\
\text { immediately and proper } \\
\text { personnel hygiene }\end{array}$ & No \\
\hline
\end{tabular}

Table 7. Example of inclusion with hazard analysis without control measure 


\begin{tabular}{|c|c|c|c|c|c|c|c|c|}
\hline (1) & (2) & (3) & (4) & & & & (5) & (6) \\
\hline \multirow{2}{*}{$\begin{array}{l}\text { Raw } \\
\text { materials and } \\
\text { process } \\
\text { steps }\end{array}$} & \multirow{2}{*}{$\begin{array}{l}\text { Potential hazard } \\
\text { state whether } \\
\text { biological, chemical } \\
\text { or physical }\end{array}$} & \multirow{2}{*}{$\begin{array}{l}\text { Rational for inclusion } \\
\text { or exclusion as a } \\
\text { hazard }\end{array}$} & \multicolumn{4}{|c|}{$\begin{array}{l}\text { Is this a significant hazard? } \\
\text { (Yes/No) }\end{array}$} & \multirow{2}{*}{$\begin{array}{l}\text { What measures } \\
\text { can be applied to } \\
\text { control this } \\
\text { significant } \\
\text { hazard? }\end{array}$} & \multirow{2}{*}{$\begin{array}{l}\text { Is this process } \\
\text { steps a CCP? } \\
\text { (Yes/No) }\end{array}$} \\
\hline & & & sev & lik & sig & $\mathrm{Y} / \mathrm{N}$ & & \\
\hline mixing & $\begin{array}{l}\text { Biology: } \\
\text { Growth of } \\
\text { pathogenic microbe } \\
\text { such B.cereus, } \\
\text { E.coli, Salmonella. }\end{array}$ & $\begin{array}{l}\text { Inclusion: } \\
\text { Likely to occur if } \\
\text { product mishandled. } \\
\text { Enforce proper } \\
\text { personnel hygiene. } \\
\text { Survival microbe will } \\
\text { be eliminated in the } \\
\text { later cooking process }\end{array}$ & 3 & 2 & 6 & $\mathrm{~N}$ & $\begin{array}{l}\text { No control } \\
\text { measure } \\
\text { required }\end{array}$ & No \\
\hline
\end{tabular}

Table 8. Example of inclusion with hazard analysis and control measure

\begin{tabular}{|c|c|c|c|c|c|c|c|c|}
\hline (1) & (2) & (3) & (4) & & & & (5) & (6) \\
\hline \multirow{2}{*}{$\begin{array}{l}\text { Raw } \\
\text { materials } \\
\text { and } \\
\text { process } \\
\text { steps }\end{array}$} & \multirow{2}{*}{$\begin{array}{l}\text { Potential hazard } \\
\text { state whether } \\
\text { biological, chemical } \\
\text { or physical }\end{array}$} & \multirow{2}{*}{$\begin{array}{l}\text { Rational for inclusion } \\
\text { or exclusion as a } \\
\text { hazard }\end{array}$} & \multicolumn{4}{|c|}{$\begin{array}{l}\text { Is this a significant } \\
\text { hazard? } \\
\text { (Yes/No) }\end{array}$} & \multirow{2}{*}{$\begin{array}{l}\text { What measures can } \\
\text { be applied to control } \\
\text { this significant } \\
\text { hazard? }\end{array}$} & \multirow{2}{*}{$\begin{array}{l}\text { Is this process } \\
\text { steps a CCP? } \\
\text { (Yes/No) }\end{array}$} \\
\hline & & & sev & lik & sig & Y/N & & \\
\hline $\begin{array}{l}\text { Storing in } \\
\text { chiller }\end{array}$ & $\begin{array}{l}\text { Biology: } \\
\text { Growth of } \\
\text { pathogenic microbe } \\
\text { such B.cereus, } \\
\text { E.coli, Salmonella. }\end{array}$ & $\begin{array}{l}\text { Inclusion: } \\
\text { Likely to occur in } \\
\text { processed product. } \\
\text { Potential failure of the } \\
\text { chiller to reach temp. } \\
0-5{ }^{\circ} \mathrm{C} \text {. }\end{array}$ & 4 & 3 & 12 & Y & $\begin{array}{l}\text { Control and } \\
\text { maintain } \\
\text { temperature at } 0-5 \\
{ }^{\circ} \mathrm{C}\end{array}$ & Yes \\
\hline
\end{tabular}

The column for rational of inclusion or exclusion hazard is often not completed correctly and can be a source of confusion (Schmidt \& Newslow 2013). The information provided for rational of inclusion or exclusion hazard should be scientific in nature. The process of rationalization of hazard by HACCP team shall consider factors related to hazard analysis that will complement the hazard analysis process after that. The solution to this misinterpretation can be minimising according to the Codex (2009); factors that should be considered are:

- Frequency of occurrence of the hazard and health severity

- Quantitative or Qualitative Assessment in the presence of the hazard

- Survival (survival) or the relevant microorganisms breeding

- Production and the creation of the hazard of toxins, chemical and physical constant in the food

- Any circumstances were leading to the incident above.

Meanwhile, Schmidt and Newslow (2013) also provide minimum factors that need to be considered during the process of rationalization and hazard analysis to this misinterpretation are:

- Ingredients and raw materials in terms of the resources available, the composition, mode of operation, methods of transportation, and keeping

- Activities are undertaken in the handling system and the production process 
- Equipment used in the process of manufacture and processing: specific main parameters to control, reduce, or prevent food hazards.

- Equipment and sanitation facilities

- Distribution of food products: transport and delivery, the practice of wholesalers and retailers, and desired uses.

Schmidt and Newslow (2013) has also brought up issue of confusion over the format of USDA/FSIS (Table 2) in terms of the significant hazard assessment questions through the question "Does the potential dangers of this should be included in the HACCP plan?". This question gives rise to confusion since all potential hazards should be included in the HACCP plan. The HACCP plan is a set of documents that not only the hazard analysis document but comprising documents such as product descriptions, process flow charts, hazard analysis worksheet, CCP worksheet and HACCP Plan Summary (Codex, 2003).

About control measures, most of the format used to put this step after hazard analysis same as the format in MS 1480: 2007. However, Schmidt and Newslow (2013) have identified the problems that arise for completing column justification and control measures due to duplication. For example, justification to significant hazard, usually done with the list control measures such as the requirement of GMP, SOP, and a metal detector for stating the hazard will not happen due to the programs established. The similar programs repeated in the column of control measures. Therefore, Schmidt and Newslow (2013) has proposed to put 'is not likely to occur' in the column justification and putting existing programs in the column control measures. This statement is in conflict with MS 1480: 2007. Where MS 1480: 2007 set the significant hazards only requires control measures and the not significant hazard do not need to set out control measures in the hazard analysis. However, confusion might happen to the HACCP team as illustrated in Table 6, where there is no hazard identified (exclusion), and hazard analysis is not done but a control measure allocated for the process.

Most hazard analysis formats put the CCP determination in the last column including MS 1480: 2007. However, Wallace et al. (2011) was proposed in her format that the last column was the justification of the selected control measures (Table 3). The format used is likely due to the determination of the CCP made using a specific format along with the questions from the decision trees results for determination of CCP. Rationally, this proposed format is more suitable to avoid pre-mature decision of the CCP determination by HACCP team. CCP established in hazard analysis format not gone through the decision tree for the confirmation yet. This statement supported by Schmidt \& Newslow (2013) who argue that CCP column in the hazard analysis format is good for the purpose of the HACCP audit and verification and attracts the HACCP team to make inaccurate decision on CCP. Example format determination of CCP Wallace et al. (2011) used as Table 9 below.

Table 9. Record of CCP determination (Wallace et al. 2011)

\begin{tabular}{|l|l|l|l|l|l|l|l|}
\hline $\begin{array}{l}\text { Process Steps } \\
\text { (hazard) }\end{array}$ & $\begin{array}{l}\text { Control } \\
\text { measure }\end{array}$ & Q1 & Q2 & Q3 & Q4 & $\begin{array}{l}\text { CCP } \\
\text { (Y/N) }\end{array}$ & $\begin{array}{l}\text { Comments by HACCP } \\
\text { Team }\end{array}$ \\
\hline & & & & & & & \\
\hline
\end{tabular}

\section{Conclusion}

In conclusion, the use of hazard analysis format in the system HACCP played a very important role in the identification of hazards, hazard analysis for identification of significant hazards, control measures and thus influence the determination of CCP directly. Misinterpretations in the hazard analysis that represents the sequence of steps the hazard analysis and determination of the CCP will affect the effectiveness of the implementation of the HACCP system and ultimately affect product safety to the consumer.

\section{Acknowledgements}

This research was self-funded and study sponsored by SIRIM Training Services Sdn Bhd, subsidiary of SIRIM Berhad. 


\section{References}

Bennet, W.L., \& Steed, L.L. (1999). An integrated approach to food safety. Quality Progress, 32; 37-42.

Codex (Joint FAO/WHO Food Standard Programme, Codex Alimentarius Commission). (2009). Hazard analysis and critical control point (HACCP) system and guidelines for its application. Italy.

Codex Alimentarius Commission (CAC) (2003). Hazard analysis and critical control point (HACCP) system and guidelines for its application. Annex to CAC/RCP 1-1969. Italy.

Department of Standard Malaysia (First revision). (2007). Malaysian Standard MS 1480: 2007. Food safety according to hazard analysis and critical control point (HACCP) system.

Department of Standard Malaysia. (2009). Malaysian Standard MS 1514: 2009. Good Manufacturing Practice (GMP) For Food (first revision).

Karl, R., \& Angus, J.K. (2000). Evaluation of worldwide approaches to the use of HACCP to control food safety. Trends in Food Science and Technology 11; 1021.

Merican, Z. (2000). The role of government agencies in assessing HACCP - the Malaysian procedure. Food Control 11(5), 371-372.

Motarjemi, Y., \& Kaferstein, F. (1999). Food safety, hazard analysis and critical control point and the increase in food-borne disease: a paradox? Food Control 10(4-5), 325-333.

Schmidt, R.H., \& Newslow, D.L. (2013). Hazard analysis critical control points (HACCP) Principle 1: Hazard analysis critical control points (HACCP) - Principle 1: Conduct a hazard analysis. FSHN 07-03, Department of Food Science and Human Nutrition, Florida Cooperative Extension Service, IFAS, University of Florida.

Soon, J.M., Singh, H., \& Baines, R. (2011). Foodborne disease in Malaysia: A review. Food Control 22, 823-830.

U.S. Department of Agriculture, Food Safety and Inspection Service (USDA FSIS). (2005). Meat and poultry hazards and controls guide.

U.S. Food and Drug Administration, Centre for Food Safety and Applied Nutrition (USFDA HACCP). (2001). Fish and fisheries products hazards and controls guidance, $3^{\text {rd }}$ Edition.

Wallace, C.A., Holyoak, L., Powell, S.C. \& Dykes, F.C. (2014). HACCP- The difficulty with Hazard Analysis. Food Control 35: $233-240$.

Wallace, C.A., Sperber, W.H., \& Mortimore, S.E. (2011). Managing HACCP and food safety throughout the global supply chain. West Sussex, UK: John Wiley \& Son, Ltd. 